\title{
An Echocardiographic Evaluation of Dilated Cardiomyopathy in a Tertiary Care Hospital
}

\author{
Raj Kumar Thapa, ${ }^{1}$ Kanchan K.C, ${ }^{2}$ Rishi Khatri, ${ }^{1}$ Devendra Khatri, ${ }^{1}$ Rajeeb K. Deo, ${ }^{1}$ Drishti Shah' \\ 'Department of Medicine, Shree Birendra Hospital, Chhauni, Kathmandu, Nepal, ${ }^{2}$ Department of Emergency and General \\ Practice, Shree Birendra Hospital, Chhauni, Kathmandu, Nepal.
}

\section{ABSTRACT}

Introduction: Cardiomyopathies are diseases of heart muscle that may originate from genetic defects, cardiac myocyte injury or infiltration of myocardial tissues. Dilated cardiomyopathy is the most common phenotype and is often a final common pathway of numerous cardiac insults. Mostly it remains unknown in the absence of echocardiography, histopathology and genetic evaluation. Though common it is underdiagnosed with not much of data available in our setup.

Methods: This study was analytical cross-sectional study of hospital data on Echocardiographic findings in 65 patients of DCM visiting cardiology unit for Echocardiographic evaluation from $1^{\text {st }}$ of February to 31 $31^{\text {st }}$ July 2018 for the period of six months in Shree Birendra Hospital, a tertiary care military hospital at Chhauni, Kathmandu. Pediatric age group patients and those who refused to give consent were excluded. Data obtained were entered in Microsoft Excel 2010 and analyzed by IBM SPSS 21.

Results: Among 65 patients enrolled 40 (61\%) were male and 25 (39\%) female with male to female ratio of 1.6:1. Elderly people (61-75 years) with an average age of 65 were commonly involved and they presented mostly with congestive heart failure, 32 (49\%). Echocardiographic evaluation showed $36(55 \%)$ with mildly dilated Left Ventricle $(5.6-6.0 \mathrm{~cm})$. Majority had reduced Left ventricular systolic function with an average Ejection fraction (EF) of 39.6\%. No significant difference between male and female with the average $\mathrm{EF} \%(\mathrm{P}=0.990)$ and there was no significant relation between age and average $\mathrm{EF} \%(\mathrm{P}=0.091)$.

Conclusions: Dilated Cardiomyopathy is the commonest cardiomyopathy phenotype mostly presenting with congestive heart failure. It is often underdiagnosed in our part of the world, however echocardiography will easily detect the condition.

Keywords: dilated cardiomyopathy; echocardiography; ejection fraction; left ventricle.

\section{INTRODUCTION}

Cardiomyopathies (CM) are diseases of heart muscle. Various etiologies such as genetic defects, cardiac myocyte injury and infiltration of myocardial tissues leads to CM. Dilated cardiomyopathy (DCM) is the most common type with enlargement of one or both of the ventricles resulting in systolic dysfunction with reduced ejection fraction (EF\%). ${ }^{1-5}$ The natural history of DCM is incompletely understood as it is caused by various agents resulting in variable presentations. ${ }^{1,6}$

Correspondence: Dr. Rai Kumar Thapa, Department of Medicine, Shree Birendra Hospital, Nepalese Army Institute of Health Sciences (NAIHS), Chhauni, Kathmandu, Nepal. Email: rthapadr2958@ gmail.com, Phone: +977-9851183939. 
The annual mortality rate has a wide range between $10 \%$ and $50 \% .^{7}$ DCM approximately accounts for $25 \%$ of the Congestive heart failure (CHF) cases and remaining $75 \%$ are due to ischemic, hypertensive or non-systolic heart failure.8,9 Genetic and specific studies in highly specialized centers can identify causes in about $50 \%$ cases and remaining are the diagnosis of exclusion, termed idiopathic variants. ${ }^{10-12}$

The aim of this study is to determine incidence, and evaluate Echocardiographic findings in patients of DCM.

\section{METHODS}

An analytical cross-sectional study was done utilizing hospital data on Echocardiographic findings in 65 patients of DCM visiting cardiology unit for Echocardiographic evaluation from $1^{\text {st }}$ of February to $31^{\text {st July }} 2018$ for the period of six months in Shree Birendra Hospital (SBH), a tertiary care military hospital at Chhauni, Kathmandu. Diagnosis of DCM was done on the basis of history, clinical features (symptoms \& signs) and Echocardiographic evaluation. Data from register book were retrieved after ethical approval from institutional review committee. Standardized questionnaire developed by the researcher was used to obtain clinical and socio-demographic characteristics of the patients after informed consent. Pediatric age group patients and those who refused to participate were excluded.

Maximum internal diameter of left ventricle (LV) during diastole less than or equal to $5.5 \mathrm{~cm}$ considered normal. $\mathrm{M}$-mode measurement of LV during systole and diastole used for calculating Ejection fraction (EF) where EF\% less than $50 \%$ considered reduced. Left ventricular diastolic dysfunction (LVDD) grade one defined by E/A ratio less than one and grade two as E/A ratio more than one (pseudo normal) with some structural LV filling defect (where, $E=$ peak velocity blood flow from gravity in early diastole and $A=$ peak velocity flow in late diastole caused by atrial contraction).

Echocardiography was performed by Cardiologists to see cardiac structural and functional abnormalities. Machine used was SIEMENS Model: ACUSON SC2000 having the facility of two dimensional view, M-mode and color flow Doppler imaging. Data obtained were entered in Microsoft Excel 2010 and analyzed by software IBM SPSS 21. Statistical significance between male and female with EF was calculated by means t-test whereas relationship between age and EF by ANOVA (analysis of variance). $\mathrm{P}<0.05$ was considered significant.

\section{RESULTS}

Among 65 patients enrolled 40 (61\%) were male and
$25(39 \%)$ female with male to female ratio of $1.6: 1$. Most of the cases have unknown etiology 53 (81\%). On Echocardiography, 36 (55\%) had mildly dilated Left Ventricle (5.6-6.0cm) (Figure 1). Additionally, dilated Left Atrium was found in 15 (23\%) cases and dilated Right Atrium along with Right Ventricle in 12 (18\%).

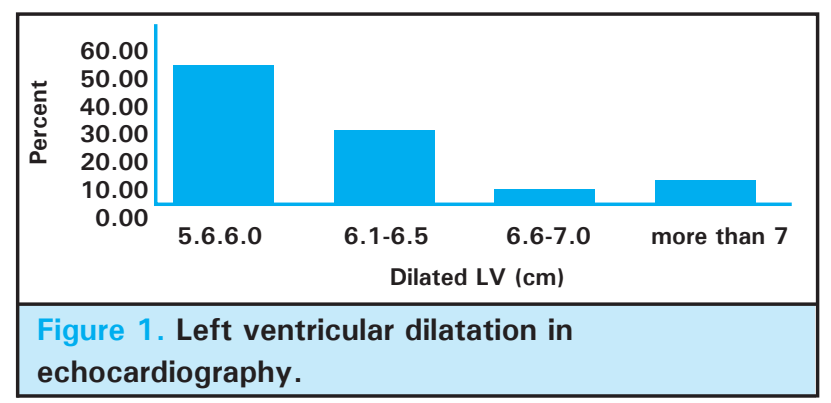

Functional Mitral regurgitation in $48(74 \%)$ with Grade I Left ventricular diastolic dysfunction in 56 (86\%). Majority had reduced Left ventricular systolic function with Ejection fraction between $21 \%$ and $30 \%$, an average of $39.6 \%$ (Figure 2).

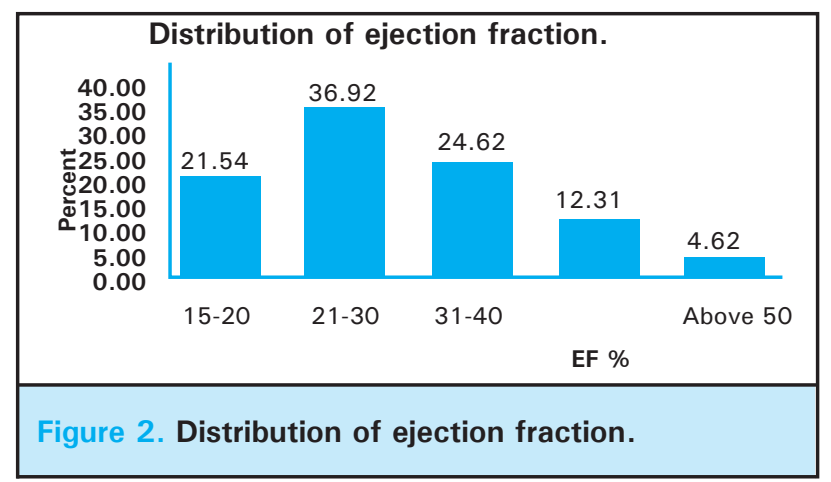

Elderly age group (61-75 years) with an average age of 65 , were encountered frequently $34(52 \%)$ and the most common clinical presentation was congestive heart failure 32 (49\%) (Figure 3).

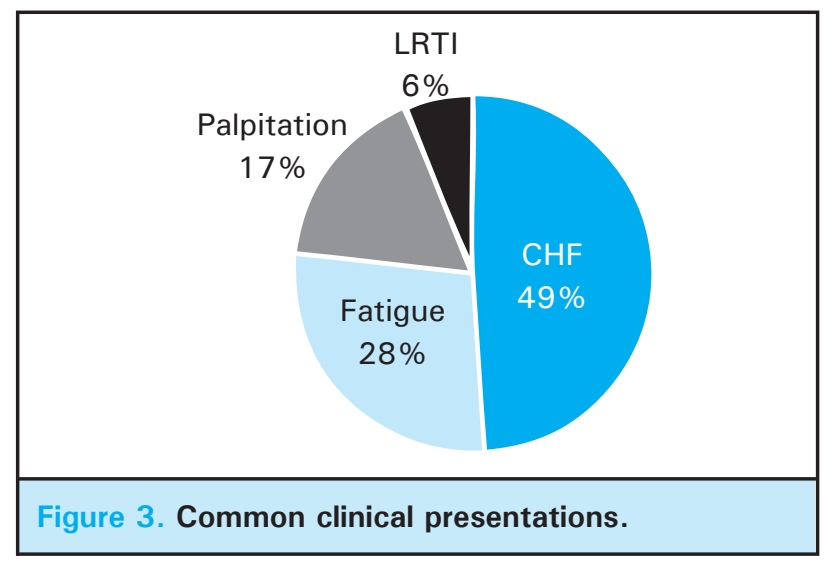

Besides, mild pericardial effusion found in $2(3 \%)$ and none of our cases had any intra-cavitary thrombus or vegetation. 
Thapa et al. An Echocardiographic Evaluation of Dilated Cardiomyopathy in a Tertiary Care Hospital

\begin{tabular}{|c|c|c|c|c|c|}
\hline Gender & $\mathbf{N}$ & Mean & $\begin{array}{l}\text { Std. } \\
\text { Deviation }\end{array}$ & $\begin{array}{l}\text { Std. Error } \\
\text { Mean }\end{array}$ & $\mathbf{P}$ \\
\hline Male & 40 & 39.6250 & 14.90945 & 2.35739 & \multirow{2}{*}{0.990} \\
\hline Female & 25 & 39.5833 & 9.19790 & 1.87751 & \\
\hline
\end{tabular}

On applying two sample means 't-test' there was no statistical significant difference between average EF\% of both male and female $(P=0.990)$ (Table 1).

Similarly, by ANOVA (Analysis of Variance) there was no relationship of age and average $\operatorname{EF} \%(P=0.091)$ (Table 2).

Table 2. Analysis of variance.

\begin{tabular}{|lrlllr|}
\hline & df & SS & MS & F & Significance F \\
Regression & 1 & 481.0212539 & 481.0213 & 2.942835 & 0.091253213 \\
Residual & 62 & 10134.21312 & 163.4551 & & \\
Total & 63 & 10615.23438 & & & \\
\hline
\end{tabular}

\section{DISCUSSION}

DCM was more common in male than female $161 \%$ vs $39 \%)$ and frequent on the elderly with the mean age of 65 years in our study population. In the study done by Suha MA et al. ${ }^{13} 53 \%$ were male and $47 \%$ female, similar to our study with males outnumbering females. Most of our patients presented with congestive heart failure $(49 \%)$ supported by Animasahun BA et al. ${ }^{14}$ where it was $54.5 \%$. Similar result was evident in the study by Towbin JA et al. ${ }^{12}$

Dilated Left ventricle (LV) is mandatory for the diagnosis of DCM, however Right ventricle (RV) may similarly be affected, Mathew T et al. ${ }^{2}$ In our study association of $\mathrm{RV}$ dilation was $18 \%$.

Incidence of functional Mitral Regurgitation (MR) in our study was $48 \%$. Functional MR, which occurs as a consequence of regional or global LV dysfunction despite a structurally normal mitral valve, is a common complication in patients with DCM, Jun $\mathrm{K}$ et al, ${ }^{3}$ Meese RB et al, ${ }^{15}$ Ballester $\mathrm{M}$ et al, ${ }^{16}$ Chandraratna PA et al. ${ }^{17}$ and its presence predicts poor outcome, Donal E et al. ${ }^{18}$

Some degree of Left ventricular diastolic dysfunction (LVDD) is inevitable in DCM ranging from grade one to four. We had $86 \%$ cases with LVDD grade one. Assessment of diastolic function in DCM also correlated by studies Nishimura RA et al, $^{19}$ Lavine SJ et al, ${ }^{20}$ Appleton CP et al. ${ }^{21}$ and Pinamonti B et al. ${ }^{22}$

LV systolic dysfunction quantified by measuring
Ejection fraction (EF) in percentage and the estimated EF\% assumes uniform or global left ventricular function, Shah PM. ${ }^{23}$ Also evidenced byFolland ED et al. ${ }^{24}$ and Stamm RB et al. ${ }^{25}$

None of our cases had intra-cavitary thrombus, however it is a common complication in patients with DCM, Asinger RW et al. ${ }^{26}$ and Gottdiener JS et al. ${ }^{27}$ The limitations of our study being the data of a single center and lack of etiologic evidence.

\section{CONCLUSIONS}

Patients commonly present with symptoms and signs of congestive heart failure and a simple Echocardiography will easily detect the condition. However, etiologic diagnosis is not possible mostly in a resource limited settings. More research works to be done to understand this common heart failure condition and our aim should be to diagnose preclinical DCM cases and thereby reduce significant mortality and morbidity.

\section{ACKNOWLEDGEMENTS}

We express our sincere gratitude to statistician Mr. Nirmal Bajracharya and Mr. Hari Khadka for their valuable expert contribution in the completion of this research.

\section{Conflict of Interest: None.}

\section{REFERENCES}

1. Hare JM. The dilated, restrictive and infiltrative cardiomyopathies. In: Bonow RO, Mann DL, Zipes DP, Libby P (Eds). Braunwald's Heart disease: A textbook of cardiovascular medicine. $9^{\text {th }}$ ed. St. Louis, Missouri: Saunders Elsevier Inc; 2011. ssp1561-81. [ Full Text]
2. Mathew T, Williams L, Navaratnam G, Rana B, Wheeler $\mathrm{R}$, Collins $\mathrm{K}$ et al. Diagnosis and assessment of dilated cardiomyopathy: a guideline protocol from the British Society of Echocardiography. Echo Res Pract. 2017 Jun 4;(2):G1-G13. [ubMed $\mid$ Full Text | DOI] 
Thapa et al. An Echocardiographic Evaluation of Dilated Cardiomyopathy in a Tertiary Care Hospital

3. Jun K, Takahiro S, Deborah AA, Zoran BP, Jian XQ, Marc AG et al. Geometric differences of the mitral apparatus between ischemic and dilated cardiomyopathy with significant mitral regurgitation: real-time three-dimensional echocardiography study . Circulation. 2003;107:1135-1140. [PubMed]

4. Tomita T, Nakatani S, Eishi K, Takemura T, Takasawa A, Koyanagi $\mathrm{H}$ et al. Effectiveness of surgical repair of mitral regurgitation concomitant with dilated cardiomyopathy. J Cardiol. 1998;32:391-96. [PubMed]

5. Blondheim DS1, Jacobs LE, Kotler MN, Costacurta GA, Parry WR. Dilated cardiomyopathy with mitral regurgitation: decreased survival despite a low frequency of left ventricular thrombus. Am Heart J. 1991;122:763-71. [PubMed]

6. Richardson P, Mckenna W, Bistow M, Maisch B, Mautner B, O'Connell J et al. Report of the World Health Organization/ International Society and Federation of Cardiology Task Force on the definition and classification of cardiomyopathies. Circulation. 1996;93:841-42. [PubMed]

7. Levy WC, Mozaffarian D, Linker DT, SutradharSC, AnkerSD, Cropp AB et al. The Seattle Heart failure model. Prediction of survival in heart failure. Circulation. 2006;113:1424-33. [PubMed]

8. Hare JM. The etiologic basis of congestive heart failure. In: Colucci W.S (eds): Atlas of Heart failure. Philadelphia. Springer, Current Medicine Group. 2002;5:29-56. [Full Text]

9. Owan TE, Hodge DO, Herges RM, Jacobsen SJ, Roger VL, Redfield MM et al. Trends in prevalence and outcome of heart failure with preserved ejection fraction. N Engl J Med. 2006;355:251-59. [PubMed | Full Text]

10. Dec GW, Fuster V. Idiopathic dilated cardiomyopathy. N Engl J Med. 1994;331:1564-75. [PubMed | Full Text]

11. Felker GM, Thompson RE, Hare JM, Hruban RH, Clemetson DE, Howard DL et al. Underlying causes and long-term survival in patients with initially unexplained cardiomyopathy. N Engl J Med. 2000;342:1077-84. [PubMed | Full Text]

12. Towbin JA, Lowe AM, Colan SD, Sleeper LA, Orav J, Clunie $S$ et al. Incidence, causes, and outcomes of dilated cardiomyopathy in children. JAMA. 2006;296:1867-76. [Full Text]

13. Suha MA, Siddig IK, Mounkaila N, Mamoun H. Prevalence and clinical presentations of dilated cardiomyopathy in Sudanese patients with heart failure. Open Science Journal. 2017 Dec;2(4). [Full Text]

14. Animasahun BA, Madise-Wobo AD, Ogunkunle OO, Gbelee $\mathrm{OH}$, Oke DA. A descriptive study about DCM in children in a tertiary hospital in Nigeria. J Clin Exp Cardiolog. 2015;2(1):102. [Full Text]

15. Meese RB, Adams D, Kisslo J. Assessment of valvular regurgitation by conventional and color flow Doppler in dilated cardiomyopathy. Echocardiography: a review of cardiovascular ultrasound and allied techniques. 1986;3(6):505-11. [Full Text]

16. Ballester M, Jajoo J, Rees S, Rickardsm A, Mcdonald L. The mechanism of mitral regurgitation in dilated left ventricle. Clin Cardiol. 1983;6(7):33-38. [Full Text | DOI]

17. Chandraratna PA, Aronow WS. Mitral valve ring in normal vs. dilated left ventricle. Chest. 1981;79(2):151-7. [PubMed | Full Text]

18. Donal E, DePlace C, Kervio G, Bauer F, Gervai R, Leclerq C et al. Mitral regurgitation in dilated cardiomyopathy: Value of both regional left ventricular contractility and dysynchrony. Eur J Echocardiogr. 2009;10(1):133-8. [PubMed]

19. Nishimura RA, Abel MD, Hatle LK, Tajik AL. Assessment of diastolic function of the heart: Background and current applications of Doppler echocardiography, Part II Clinical studies. Mayo Clin Proc. 1989;64(2):181-204. [Full Text | DOI]

20. Vine SLA. Left ventricular diastolic function in idiopathic cardiomyopathy: Doppler hemodynamic, correlations. Echocardiography. 1991;8(2):151-61. [Full Text]

21. Appleton CP, Hatle LK, Popp RL. Relation of transmitral flow velocity patterns to left ventricular diastolic function: New insights from a combined hemodynamic and Doppler echocardiographic study. J Am Coll Cardiol. 1988;12(2):426-40. [PubMed | Full Text | DOI]

22. Pinamonti B, Lenarda AD, Sinagra G, Camerini F. Restrictive Left ventricular filling pattern in dilated cardiomyopathy assessed by Doppler Echocardiography: Clinical, Echocardiographic and hemodynamic correlations and prognostic implications. J Am Coll Cardiol. 1993;22(3):808-15. [PubMed]

23. Shah PM. Echocardiography in Congestive or Dilated Cardiomyopathy. J Am Soc ECHO. 1988;1(1):20-30. [Full $\underline{\text { Text }}$ | DOI]

24. Folland ED, Paris AF, Moynihan PF, Jones DR, Feldman CL, Tow DE. Assessment of left ventricular ejection fraction and volumes by real-time, two-dimensional echocardiography. Circulation. 1979;60(4):760-6. [PubMed]

25. Stamm RB, Carabello BA, Meyers DL, Martin RP. Two-dimensional echocardiographic measurement of left ventricular ejection fraction: Prospective analysis of what constitutes an adequate determination. Am Heart J. 1982;104(1):136-44. [uued | Full Text | DOI]

26. Asinger RW, Mikell FL, Sharwa B et al. Observations on detecting left ventricular thrombus with two-dimensional echocardiography: Emphasis on avoidance of false positive diagnosis. Am J Cardiol. 1981;47(1)145-56. [PubMed]

27. Gottdiener J, Voorhees LV, Gay J, Di Bianco R, Fletcher R. Incidence and embolic potential of left ventricular thrombus in cardiomyopathy: Assessment by two-dimensional echocardiography. Am J Cardiol. 1982;49(4):1029. [Full Text I DOI]

\footnotetext{
The Author(s) 2018.
}

This work is licensed under a Creative Commons Attribution 4.0 International License. The images or other third party material in this article are included in the article's Creative Commons license, unless indicated otherwise in the credit line; if the material is not included under the Creative Commons license, users will need to obtain permission from the license holder to reproduce the material. To view a copy of this license, visit http://creativecommons.org/licenses/by/4.0/ 